\title{
COMPARISON OF CONCRETE COMPRESSIVE STRENGTH VALUES OBTAINED USING REBOUND HAMMER AND DRILLED CORE SPECIMENS
}

Raimondas SADZEVICIUS Institute of Hydraulic Constructural Engineering, Aleksandras Stulginskis University, Universiteto g. 10, LT-53361 Akademija, Kauno raj., raimondas.sadzevicius@ asu.lt (corresponding author)

Tatjana SANKAUSKIENE, Institute of Hydraulic Constructural Engineering, Aleksandras Stulginskis University, Universiteto g. 10, LT-53361 Akademija, Kauno raj., tatjana.sankauskiene@asu.lt

Petras MILIUS, Institute of Hydraulic Constructural Engineering, Aleksandras Stulginskis University, Universiteto g. 10, LT-53361 Akademija, Kauno raj., petras.milius@asu.lt

Durability of reinforced concrete structures depends on the maintenance conditions, surveillance, and well-timed repair of structures or reconstructions. Usually, the main attention falls on the durability determination based on the evaluation of change of main physical -mechanical properties, especially, on the compression strength of concrete. In this study, tests with the rebound hammer and concrete cores extracted from the existing reinforced concrete elements in hydraulic structures are presented. The comparison of strength values obtained with the rebound hammer and the concrete core specimens of reinforced concrete in hydraulic structures is carried out. The research was performed during the scientific expedition in the period of 2010-2014. The investigated objects are allocated in hydroschemes of Druskininkai, Marijampole, Klaipèda districts. It was established that the results obtained using the non-destructive method were by $17 \%$ higher than the ones obtained by performing the destructive test. However, it can be said that despite this fact, the non-destructive method offers simplicity and rapidity in use: test results are readily available on site and there is a possibility to test concrete strength of those structures where cores cannot be drilled due to thin-walled or densely reinforced structures.

Keywords: Rebound hammer, concrete core strength, reinforced concrete hydraulic structures.

\section{INTRODUCTION}

The analysis of technical state of hydraulic structures of 155 dams constructed in Lithuania (Patašius, 2009), reveals that almost every concrete structure in the investigated objects experiences continuous minor deterioration due to the severe climate. A thorough and logical evaluation of the current state of concrete in a structure is the first step of any repair or rehabilitation project (EM 1110-2-2002; Venckevičius, Žilinskas, 2000).

This evaluation may include a review of design and construction documents, a review of structural instrumentation data, a visual examination, non-destructive testing (NDT), and a laboratory analysis of concrete samples.

In this paper the results of visual examination, non-destructive testing (NDT), and laboratory analysis of concrete specimens are discussed. Field observations were used in order to evaluate the exposed concrete, to identify and to define the areas of distress. It is considered that core drilling, which was used to obtain concrete specimens for the laboratory analysis or testing is the best method of obtaining information about the state of concrete within a structure. However, since core drilling is expensive, it should only be considered when sampling and testing of interior concrete is necessary (EM 1110-2-2002).

The main advantage of non-destructive test methods is that they do not damage or affect the structural performance of components of the building. They offer simplicity and rapidity in use: test results are readily available on site. In addition, the applied testing equipment is less expensive and there is a possibility of testing concrete strength in structures where cores cannot be drilled (they are thin-walled, densely reinforced, etc.). This also reduces labour consumption of testing and preparatory work, such as tedious work associated with determining location and diameters of reinforcement bars (Kiviste, Miljan, 2007).

Concrete testing with the original SCHMIDT Hammer is the most frequently used method worldwide for the non-destructive testing of concrete and its structural components. The rebound hammer can be used on laboratory specimens or in-situ concrete. The test hammer hits the concrete with a defined energy. Its rebound depends on the hardness of concrete and is measured by the testing equipment. Based on the conversion chart, the rebound value can be used to determine the compressive strength. Most researchers apply rebound hammer to test standard cylinders or

Copyright (C) 2015 The Authors. Published by Aleksandras Stulginskis University. This is an open-access article distributed under the terms of the Creative Commons Attribution License (CC-BY 4.0), which permits unrestricted use, distribution, and reproduction in any medium, provided the original author and source are credited. 
cubes, the concrete mixtures of which are prepared in the laboratory. A good relation between compressive strength and rebound number for concrete cylinders made in the laboratory was already established in late 1950s (Grieb 1958; Willetts, 1958). Nevertheless, there is a little number of research papers, where rebound hammer test is compared to the method of concrete cores extracted from the existing concrete structures (Kiviste, Miljan, 2007).

A summary of the rebound hammer test during field observations and compressive test of concrete cores in laboratory is presented in this paper.

Object of research - reinforced concrete structures of hydroschemes located in Druskininkai, Marijampolè, Klaipèda districts.

Aim of research - to find out the possible correlation between the Schmidt hammer rebound number and compressive strength of concrete cores drilled from the reinforced concrete elements in hydraulic structures.

Tasks to reach the aim:

- to evaluate the compressive strength of concrete in hydraulic structures using rebound hammer test during field observations;

- to evaluate the compressive strength of concrete cores using compressive test in laboratory;

- to compare the results of compressive strength of concrete obtained by carrying out the field investigations using rebound hammer and by drilling the cores from the reinforced concrete elements.

\section{RESEARCH METHODS}

According to the researches carried out in 2012-2014 by the researchers of the Institute of Hydraulic Structure Engineering (former - Department of Building Constructions) in Aleksandras Stulginskis University, 3 objects with reinforced concrete structures in Druskininkai, Marijampolè, Klaipėda districts were chosen.

Object 1 is the reinforced concrete constructions of the pavilion of aerohydro-ionization therapy, which is situated on Ratnyčia River in Druskininkai Healthcare Park. According to the technical data of the building, it was constructed in 1954 and reconstructed in 2015. This object is considered as potentially non dangerous. The investigations and field observations of hydraulic structures were carried out from the $11^{\text {th }}$ to $19^{\text {th }}$ of July in 2013 .

Object 2 is the reinforced concrete constructions of the embankments No. 80 and 81 situated in the territory of the Port of Klaipeda, on the eastern side of Danè River, in the area of the Curonian Lagoon. According to the technical data, the embankments were reconstructed in 2012. This object is considered as potentially dangerous. The investigations and field observations of hydraulic structures were carried out on the $13^{\text {th }}$ of August in 2012 .

Object 3 is the reinforced concrete constructions in the hydroscheme of Marijampole hydropower plant situated on Šešupe River. According to the technical data, the reservoir was created in 1935. The spillway was reconstructed in 1958, 1984 and 1998. This object is considered as potentially dangerous. The investigations and field observations of hydraulic structures were carried out from the $28^{\text {th }}$ of February to the $20^{\text {th }}$ of May in 2014.

In order to analyze the technical state of reinforced concrete structures in hydroschemes, the following diagnostic methods were used: visual examination, field observations, photofixation, non-destructive and destructive methods for the estimation of compressive strength of concrete (ACI 210R-93; ACI 210.1R-94).

Visual examination is the examination of an object when the simplest necessary measurements are made using such simple tools as a tape-measure, a ruler, a sliding caliper, a camera and a plumb line.

Photofixation method is a method when everything is sequentially photographed.

The compression strength of concrete structures was estimated using non-destructive and destructive methods in accordance with the requirements of the Standard and the instruction manual of instrument devices (EN 12504-2:2012, EN 12504-1:2009, EN 12390-3:2009).

Using the non-destructive method with a rebound hammer of concrete Cat.58-CO181/N (Schmidt's system), an actual compressive strength of concrete was measured. The non-destructive testing of compression strength was performed in accordance with the Standard EN 12504-2:2012, using the Schmidt Hammer, the calibrated rebound device which was produced by the Swiss company "Proceq", serial No. N-34 160752. Before and after every examination, the device was calibrated using the standard anvil. The examination areas were prepared using abrasive stone (Fig. 1).

In accordance with the usage instructions of the instrument, 10-12 hits were made to test the concrete with the rebound hammer in specially prepared areas of construction. Research results were statistically evaluated: the average compressive strength of concrete $f_{c}$, the variation coefficient $v$ and the root-mean-square deviation $\sigma$ were calculated using "Microsoft Excel" macros.

The rebound number depends on such factors affecting the concrete surface as the degree of saturation, carbonation, temperature, surface preparation and location, also the type of surface finish. Moreover, the result is affected by the type of aggregate and the proportions of mixture. Schmidt hammer instruction manual indicates that if concrete has served for more than 5 years, it is necessary to evaluate the increased solidity of the concrete in the surface layer due to carbonization (the reactions between $\mathrm{Ca}(\mathrm{OH})_{2}$ in the concrete and $\mathrm{CO}_{2}$ in the air, the product of which is $\mathrm{CaCO}_{3}$ ). In order to evaluate carbonization, all the compression strength values have to be multiplied by 0,7 - the evaluation of the effect of concrete ageing, inasmuch as the strength of concrete is lower in deeper layers.

In order to estimate the concrete compressive strength using the destructive method, cylindrical cores (diameter $-100 \mathrm{~mm}$, height $-110-300 \mathrm{~mm}$ ) were drilled (Fig. 2). The testing was carried out according to the requirements of the Standard EN 12504-1:2009 "Concrete testing in structures. Part 1. Cores. Sampling, observation and compression tests". 


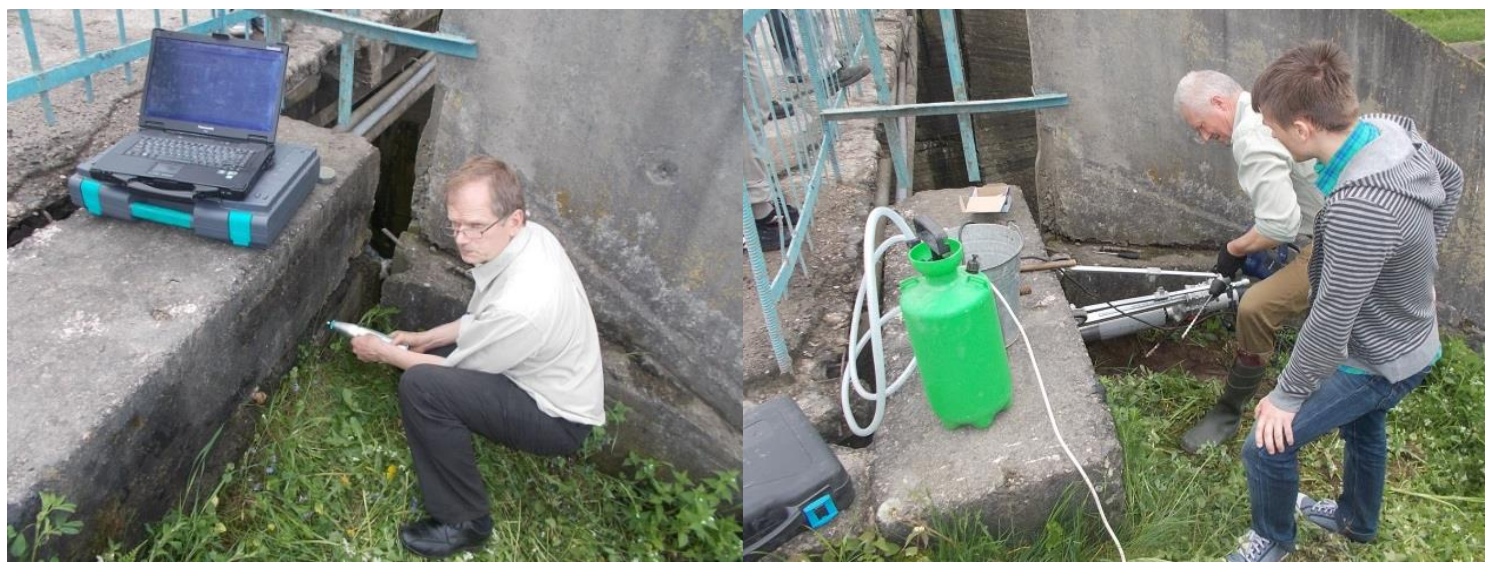

Figure 1. The estimation of compression strength using the non-destructive method

Figure 2. Cores' drilling process and device specification

Before drilling, the position of steel armature and the thickness of concrete layer above it were being evaluated using Profometer 5+ Scanlong device (produced in Switzerland, "Proceq") in order to avoid the presence of armature in specimens, especially along the cylinder, as it disturbs the process of testing the strength of concrete (Fig. 3).

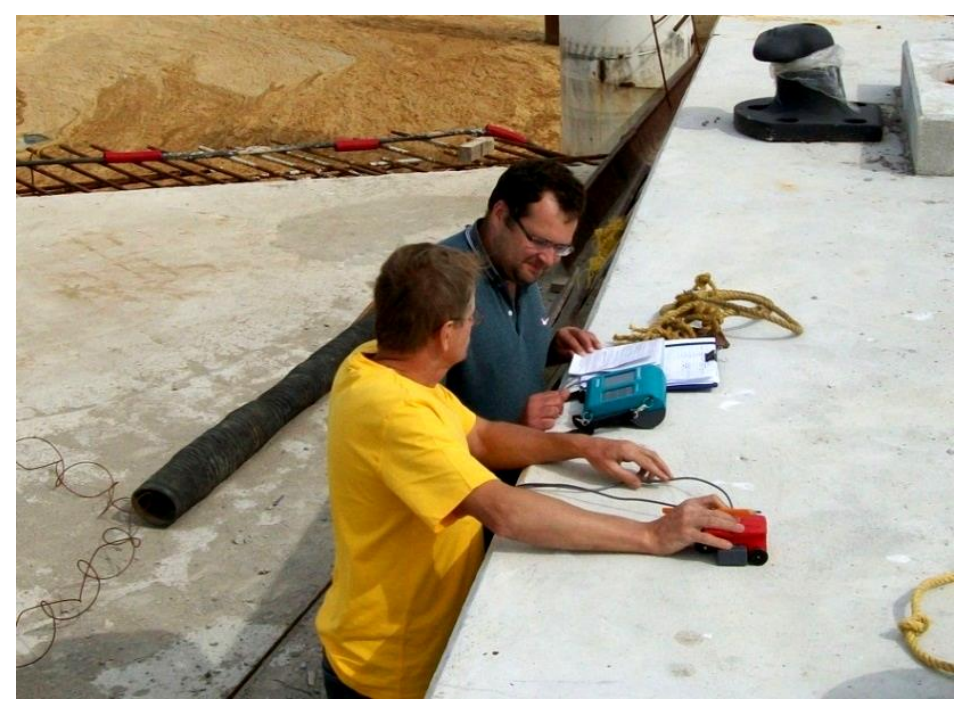

Figure 3. Defining position and depth of the armature using Profometer 5+ Scanlong

The drilled cores were prepared by cutting off their ends and grinding them, after that they were tested in the laboratory using compression machine - hydraulic press CONTROLS MCC 8 (Fig. 4.).

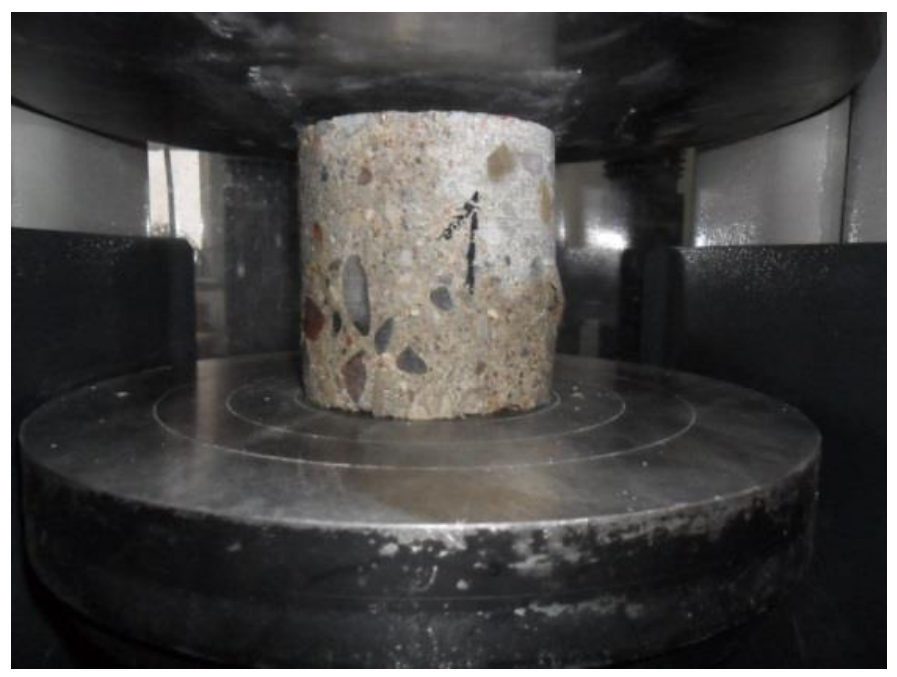

Figure 4. Compression test using hydraulic press CONTROLS MCC 8 
In accordance with the Standard EN 206-1:2002 "Concrete. Part 1. Technical requirements, features, production, concordance" and the compression strength results obtained using both non-destructive and destructive methods, the characteristic, which is guaranteed by $95 \%$ of probability, compression strength $f_{c m}$ was established.

\section{RESULTS AND DISCUSSION}

Main physical-mechanical property of reinforced concrete structures - their concrete compression strength was determined and statistically evaluated using such standard methods as field investigations and laboratory tests (Fig. 3). In this paper the data of reinforced concrete structures of 3 functioning hydraulic structures and its analysis are presented. Hydraulic structures selected for the investigations are situated in Druskininkai, Klaipeda and Marijampole districts. The oldest object was built in 1935, the newest one was reconstructed in 2015. The investigations were carried out between 2012 and 2014.

The estimated compression strength of concrete was calculated to cube strength $f_{c m}$ using statistically evaluated values of an average compressive strength of concrete $f_{c}$ (STR 2.05.05:2005).

The reinforced concrete strength $f_{c m}$ of the constructions in the pavilion of aerohydro-ionization therapy, which is situated on Ratnyčia River in Druskininkai Healthcare Park was determined by using non-destructive and destructive methods. Figure 5 shows the results.

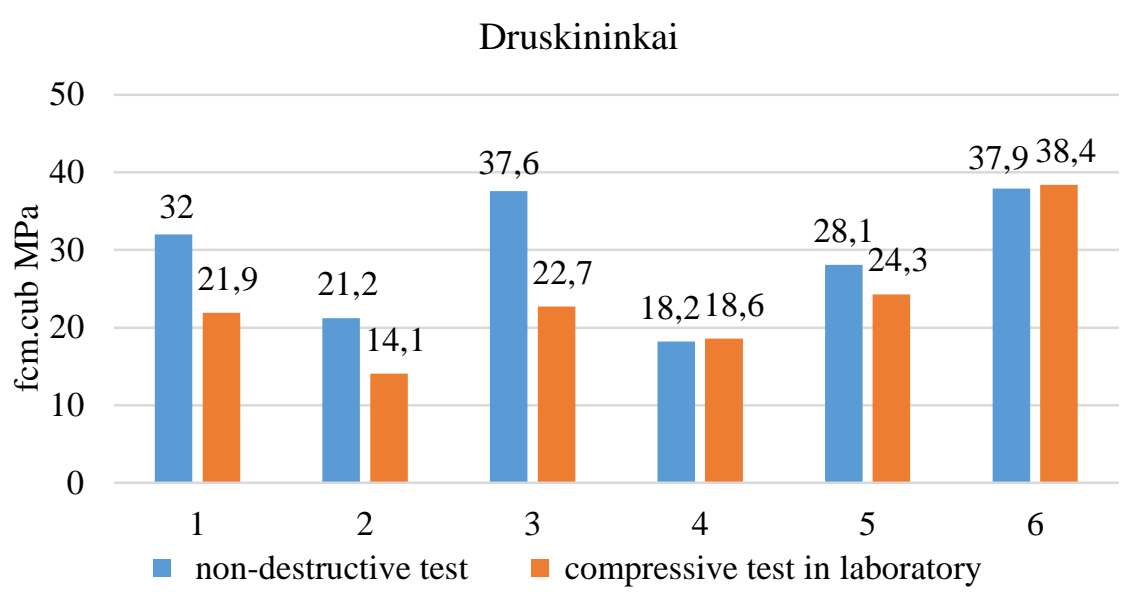

Figure 5. Compression strength of concrete in hydraulic structures of Druskininkai

By using the non-destructive method, the highest concrete compression strength $f_{c m}=37.9 \mathrm{MPa}$ of the transition zone of the second crosswall in the constructions of the pavilion of aerohydro-ionization therapy was determined. Then, according to the destructive method, a core was drilled from this wall and tested in the laboratory, finally, the highest concrete compression strength $f_{c m}=38.4 \mathrm{MPa}$ was determined. Having performed the non-destructive test, the lowest concrete compression strength $f_{c m}=18.2 \mathrm{MPa}$ was determined in the front wall of the transition zone and a very similar number $f_{c m}=18.6 \mathrm{MPa}$ was determined by performing the destructive test. Figure 6 presents the results which show, that the compression strength of 6 specimens determined using the non-destructive method is by $19 \%$ higher than the one determined by means of compressing the cores.

The concrete compression strength $f_{c m}$ of reinforced concrete constructions in the embankments No. 80. 81 situated in the territory of the Port of Klaipeda was established by using the non-destructive and destructive methods.

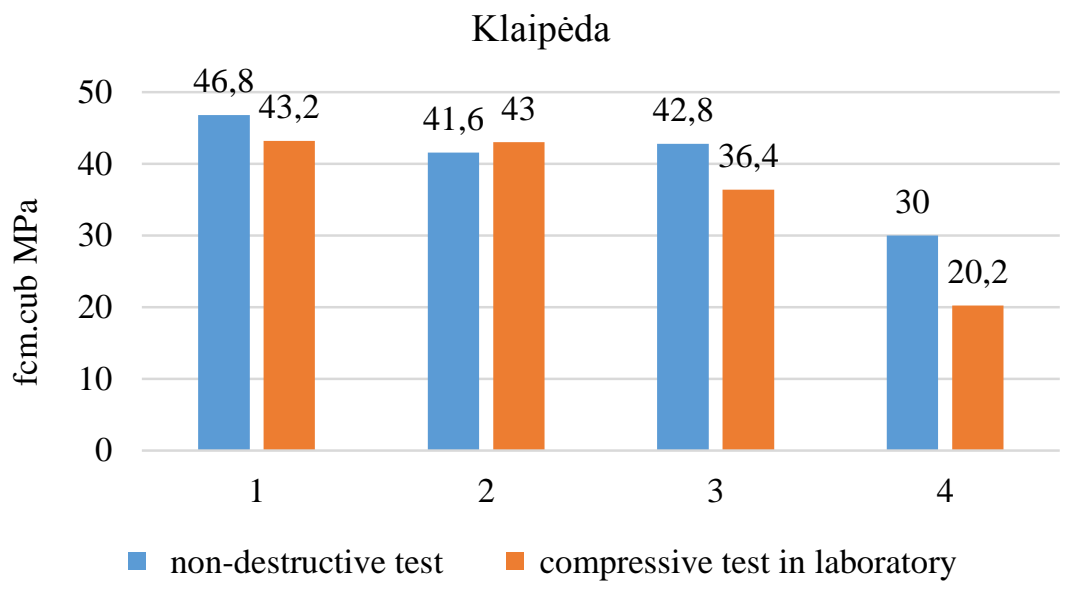

Figure 6. Compression strength of concrete in hydraulic structures of Klaipeda 
By using the non-destructive method, the highest concrete compression strength $f_{c m}=46.8 \mathrm{MPa}$ was determined in the wall of the embankment No. 81, and the destructive test gave the result of $f_{c m}=43.2 \mathrm{MPa}$. Next, by using the non-destructive method, the lowest concrete compression strength $f_{c m}=30.0 \mathrm{MPa}$ was established in the wall of the embankment No. 80, nevertheless the strength in this wall established using the destructive method $f_{c m}=20.2 \mathrm{MPa}$ was by $33 \%$ lower. Figure 6 presents the results, which show that the compression strength of concrete $f_{c m}$ of 4 specimens established using the nondestructive test, is by $12 \%$ higher than the one established after the compressive test in laboratory.

The compressive strength of the reinforced concrete constructions in the hydroscheme of Marijampole hydropower plant on Šešupe River is presented in figure 7.

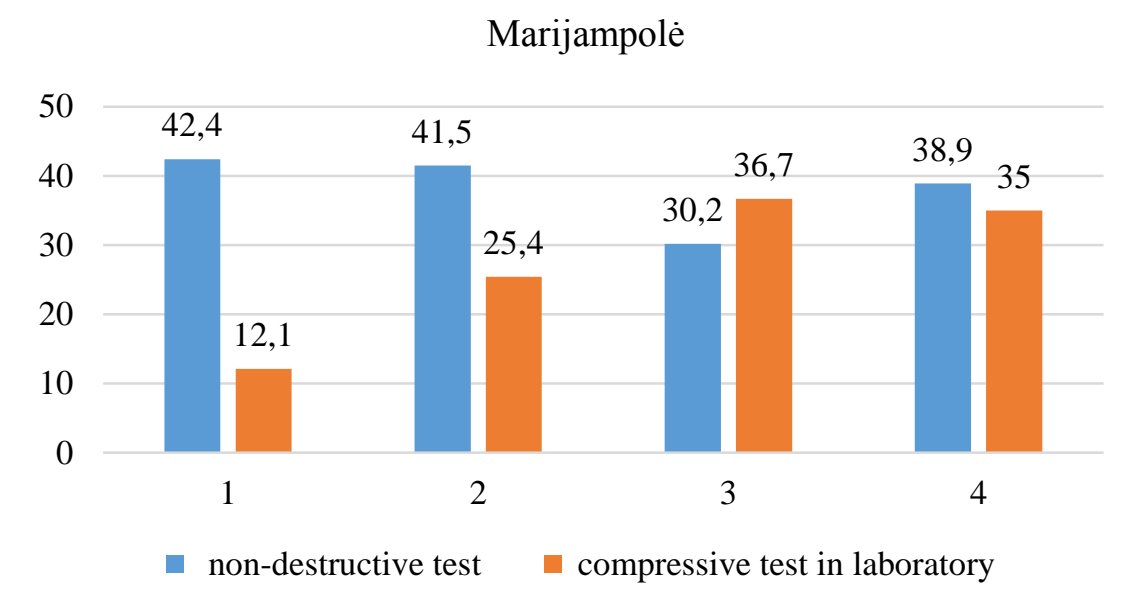

Figure 7. Compression strength of concrete in hydraulic structures of Marijampole

After the the non-destructive test, the highest concrete compression strength $f_{c m}=42.4 \mathrm{MPa}$ of reinforced concrete constructions in hydroscheme of Marijampole hydropower plant was determined in the wall of the right abutment of the downstream part, however the examination using the destructive method gave the result of $f_{c m}=12.1$ which is by $71 \%$ lower. By performing the non-destructive test, the lowest concrete compression strength $f_{c m}=30.2 \mathrm{MPa}$ was established in the wall of the left abutment, however the strength in this wall established using the destructive method $f_{c m}=36.7 \mathrm{MPa}$ was by $22 \%$ higher. As it can be seen in figure 7, the concrete compression strength $f_{c m}$ of 4 specimens established using the non-destructive method, is by $24 \%$ higher than the one established by performing the compression of cores.

Having compared the results of concrete compression strength of 24 specimens, it was established that the results obtained using the non-destructive method (Schmidt Hammer) were by $17 \%$ higher than the ones obtained by performing the compression test. It is known, that the rebound hammer test shows only the state of the surface of concrete, therefore the result of compressive strength obtained by examining the drilled cores is more reliable, but it should be noted that the strength of cores should not be equated with the strength of standard test specimens. The strength of cores is lower than that of standard cylinders, partly as consequence of the drilling operation and partly because site curing is almost invariably inferior to curing established for standard specimens. However, it is necessary to perform the drilling carefully, due to a high risk of slight damage: in our case, some specimens were strongly damaged by cracks and certain failures of cores extractions could not be avoided (Fig. 8). Different researchers suggest reducing the strength values: V. M. Malhotra (1977) suggests that the reduction in strength should be as high as $15 \%$ for the concrete of $40 \mathrm{MPa}$, and Concrete Society (1976) suggests that it should be $7 \%$ for the concrete of $5 \mathrm{MPa}$.

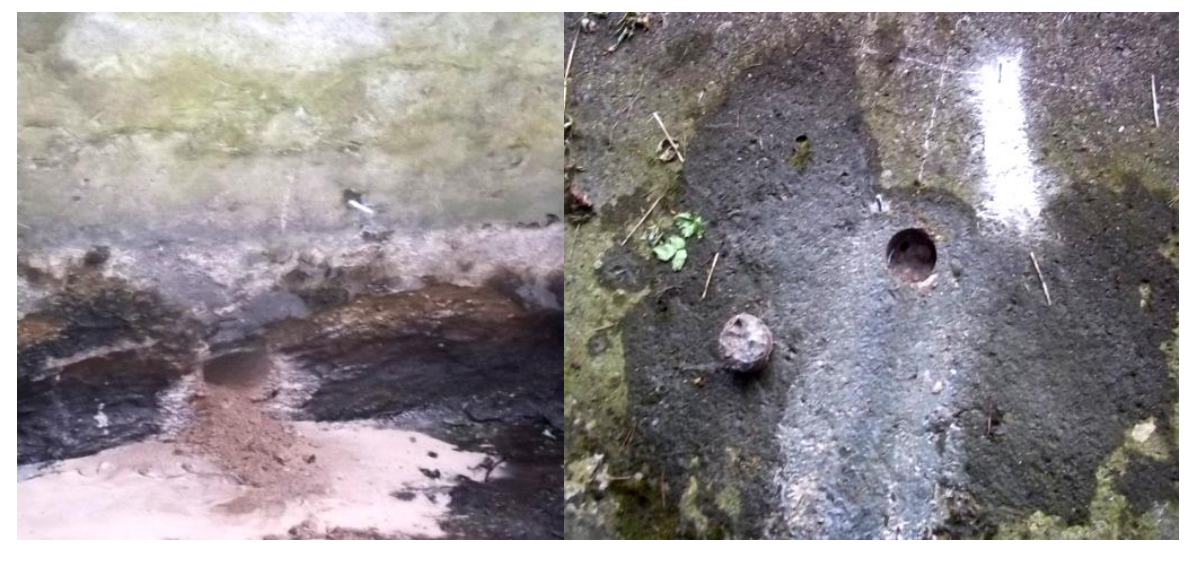

a

b

Figure 8. Failed extractions of cores when a) the strength of concrete was too low; b) the thickness of slab was too low 
Despite the slightly higher results of concrete compression strength obtained by performing non-destructive test, this method offers simplicity and rapidity in use: test results are readily available on site and there is a possibility to test concrete strength of those structures where cores cannot be drilled due to thin-walled or densely reinforced structures, etc.

\section{CONCLUSIONS}

1. The following results of concrete compression strength were obtained using the non-destructive method during the field observations:

a) in the constructions of the pavilion of aerohydro-ionization therapy in Druskininkai, the highest concrete compression strength is $f_{c m}=37,9 \mathrm{MPa}$ and the lowest concrete compression strength is $f_{c m}=18,2 \mathrm{MPa}$;

b) in the embankments No. 80,81 situated in the territory of the Port of Klaipeda the highest concrete compression strength is $f_{c m}=46,8 \mathrm{MPa}$ and the lowest concrete compression strength is $f_{c m}=30,0 \mathrm{MPa}$;

c) in the reinforced concrete constructions of hydroscheme of Marijampole hydropower plant, the highest concrete compression strength is $f_{c m}=42,4 \mathrm{MPa}$ and the lowest concrete compression strength is $f_{c m}=30,2 \mathrm{MPa}$;

2. The following results of concrete compression strength were obtained using the destructive method in laboratory:

a) in the constructions of the pavilion of aerohydro-ionization therapy in Druskininkai, the highest concrete compression strength is $f_{c m}=38,4 \mathrm{MPa}$ and the lowest concrete compression strength is $f_{c m}=18,6 \mathrm{MPa}$;

b) in the embankments No. 80, 81 situated in the territory of the Port of Klaipeda the highest concrete compression strength is $f_{c m}=43,2 \mathrm{MPa}$ and the lowest concrete compression strength is $f_{c m}=20,2 \mathrm{MPa}$;

c) in the reinforced concrete constructions of hydroscheme of Marijampole hydropower plant, the highest concrete compression strength is $f_{c m}=36,7 \mathrm{MPa}$ and the lowest concrete compression strength is $f_{c m}=12,1 \mathrm{MPa}$;

3. Having compared the results of concrete compression strength of 24 specimens obtained from all the three objects, it was established that the results obtained using the non-destructive method (Schmidt hammer) were by $17 \%$ higher than the ones obtained using the destructive method by compressing the cores.

4. Despite the fact that the results obtained using the destructive method are considered to be more reliable, in some cases, it is necessary to use the non-destructive methods, for instance, when it is impossible to drill the cores due to weak concrete or thin-walled structures, etc.

\section{REFERENCES}

1. ACI 210R-93. ACI Manual of Concrete Practice Part 1, 2001. Erosion of Concrete in Hydraulic structures. American Concrete institute, Farmington hills, $24 \mathrm{p}$.

2. ACI 210.1R-94. Compendium of Case Histories on Repair of Erosion- Damaged Concrete in Hydraulic Structures, 1999,33 p.

3. CONCRETE SOCIETY, Concrete core testing for strength, 1976. Technical Report No. 11, London, 44 p.

4. EN 12504-1:2009 Testing concrete in structures - Part 1: Cored specimens - Taking, examining and testing in compression.

5. EN 12504-2:2012 Testing concrete in structures - Part 2: Non-destructive testing - Determination of rebound number.

6. EN 13791:2007 Assessment of in-situ compressive strength in structures and precast concrete components

7. EN 12390-3:2009. Testing hardened concrete - Part 3: Compressive strength of test specimens.

8. EN 206-1:2002/A1:2004/A2:2005 Concrete - Part 1: Specification, performance, production and conformity.

9. EM 1110-2-2002. Evaluation and Repair of Concrete Structures. Department of the Army U.S. Army Corps of Engineers. Washington, USA, $185 \mathrm{p}$.

10. Grieb, W. E., 1958. Use of the Swiss hammer for estimating the compressive strength of hardened concrete. Public Roads, 30 No. 2, Washington DC, pp. 45-50.

11. Willetts, C. H., 1958. Investigation of the Schmidt concrete test hammer. Miscellaneous Paper No. 6-267 U.S. Army Engineer Waterways Experiment Station, Vicksburg, Miss.

12. Kiviste, M., Miljan, J., 2007. Structural Concrete Compressive Strength Determination with Rebound Hammer. LŽŪU mokslo darbai, Nr. 47 (27)1.

13. Malhotra, V. M., 1977. Contact strength requirements - cores versus in situ evaluation. Journal of American Concrete Institute, Vol. 74, No. 4, pp. 163-172.

14. Patašius, A., Damulevičius, V., Šadzevičius, R., 2009. “ Preparation of recommendation for evaluation of technical state of Lithuanian hydro schemes based on analysis of data obtained by questionary and field investigations " (in lithuanian), Kaunas, 102.

15. STR 2.05.05:2005. Design of concrete and reinforced concrete structures (in lithuanian). Vilnius, LSD, [online] [accessed on 24.09.2014]. Available: http://www3.lrs.lt/pls/inter3/dokpaieska.showdoc 1?p id=249853

16. Venckevičius, V., Žilinskas, R., 2000. Reconstruction and repair of buildings. Kaunas, 315 p. (in Lithuanian) 